\section{Questión}

Periodismo / Comunicación ISSN 1669-6581
- Av. $44 \mathrm{~N}^{\circ} 676,1^{\circ}$ piso

CP 1900 - La Plata - Argentina

www.perio.unlp.edu.ar/question

Cora Gamarnik

DOI: https://doi.org/10.24215/16696581e332

\title{
Leer una fotografía en tiempos de pandemia
}

\section{Read a photograph in times of pandemic}

Cora Gamarnik

Doctora en Ciencias Sociales y Licenciada en Comunicación por la Universidad de Buenos Aires. Profesora titular de Didáctica de la Comunicación de la Facultad de Ciencias Sociales de la UBA. Docente de postgrado en la maestría en Historia Contemporánea de la Universidad Nacional de General Sarmiento y en FLACSO (Facultad Latinoamericana de

Ciencias Sociales). Profesora asociada en la Universidad Nacional de Moreno. Coordinadora del Área de Estudios sobre Fotografía de la Facultad de Ciencias Sociales, UBA y del programa de Actualización en Fotografía y Ciencias Sociales FSOC-UBA. Ha publicado numerosos artículos en libros y revistas especializadas de Argentina y del exterior. 


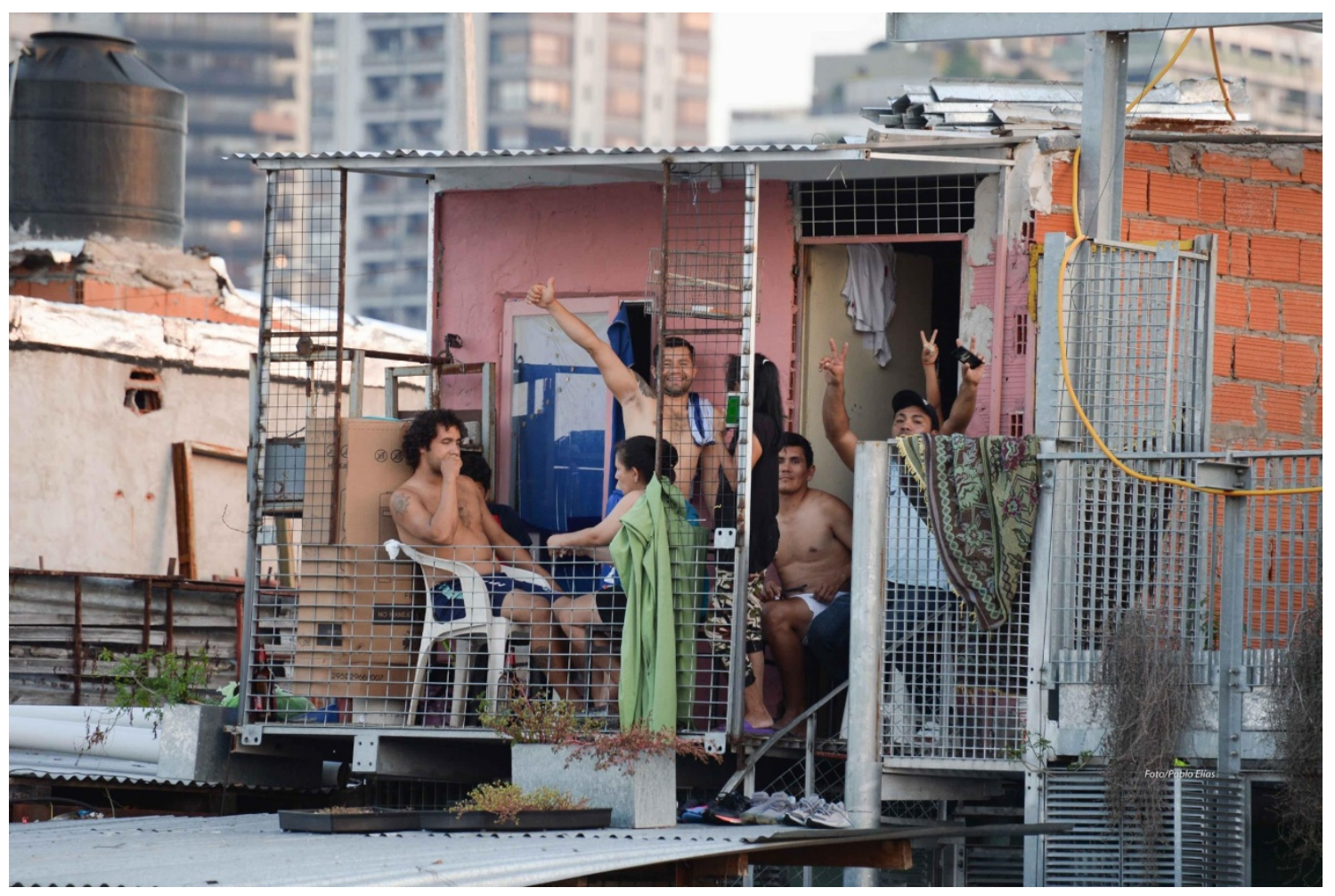

¿Quién sabe no? ¿Quién sabe cómo la llevan otros?

Quién sabe desde dónde va a venir la esperanza...

Los dedos en V sin soltar el celular. Los dedos en V sin salir siquiera en la foto, en la mano de alguien que quedó tapado ahí en el fondo. Uno quedó de pie, tal vez no hay más sillas o tal vez ya no hay lugar en el balcón. Él es el que tiene la sonrisa amplia y hace el signo de que todo va a estar bien.

Todos en cuero, pasando el tiempo, sin mate en esta vuelta.

Saludan al fotógrafo, lo registran, lo festejan.

Un muchacho y una mujer en su mundo. Haciendo un espacio propio donde no lo hay. Ensimismados. Sillas de plástico y banquitos. La alfombra y la colcha verde colgadas ahí afuera. $\mathrm{Y}$ canaletas arriba del techo que no se pudieron colocar o que sobraron vaya uno a saber.

Hay algunas plantas en macetas pero una ya se secó. 
El rosa despintado de la pared contrasta con la toalla azul que hace a la vez de cortina. $Y$ una manguera amarilla lleva agua desde un tanque hacia quien sabe donde.

Los ocho en el balcón, en el balcón de tres metros por uno. En ese balcón construido como un puzzle de legos, cima de una torre endeble hecha de materiales que sobran, que se encuentran por ahí o que se compran con esfuerzo.

Una escalera caracol se intuye pero no se ve. En el techo que está lindante hay lugar para fuentes con plantas y una maceta.

También para poner muy ordenadas todas las zapatillas que se sacan antes de entrar.

¿Quién sabe no? ¿Quién sabe cómo la llevan otros?

Quién sabe desde dónde va a venir la esperanza...

Fotografía Pablo Elías/ @pabloeliasfotos

Villa 31 - Retiro- 31 de marzo de 2020

Audio (edición del Programa Pateando el Patriarcado. Fm Tinkunaco-José C. Paz)

Preguntas de una mujer ante un virus:

https://ar.ivoox.com/es/51074420 